University of California, Hastings College of the Law UC Hastings Scholarship Repository

Published Scholarship

The Honorable Roger J. Traynor Collection

1935

\title{
The Model Real Property Tax Collection Law
}

Roger J. Traynor

Follow this and additional works at: http://repository.uchastings.edu/traynor_scholarship_pub

\section{Recommended Citation}

Roger J. Traynor, The Model Real Property Tax Collection Law , 24 CALIF. L. REV. 98 (1935).

Available at: http://repository.uchastings.edu/traynor_scholarship_pub/6

This Article is brought to you for free and open access by the The Honorable Roger J. Traynor Collection at UC Hastings Scholarship Repository. It has been accepted for inclusion in Published Scholarship by an authorized administrator of UC Hastings Scholarship Repository. For more information, please contact marcusc@uchastings.edu. 
6

Box 1

Folder 


\section{Legislation}

The Model Real Property Tax Collection Law. ${ }^{1}$-Municipalities, heavily burdened by the cumulative tax delinquency of the past decade, must find some way of lessening the strain that threatens to disrupt their credit. ${ }^{2}$ Like the federal and state governments, they have assumed responsibility not merely for large emergency relief projects, but for a permanent enlargement of governmental equipment and services; meanwhile they have continued to depend for the bulk of their resources upon the rigid general property $\operatorname{tax},{ }^{3}$ which contracts with deflated real estate values in times of greatest need. Both the uneconomic nature of this tax and the frequency of inequitable assessment valuations $^{4}$ have aggravated the critical state of municipal credit, but the major responsibility lies with inefficient collection, which has obstructed the receipt of taxes in good times as in bad. The lack of flexible arrangements for payments by taxpayers in real financial distress has frozen indefinitely their capacity to pay. At the same time inadequate penalties and lax enforcement against voluntary delinquency have demoralized the certainty and promptness of all tax receipts and vitiated efforts at tardy enforcement. While unpaid taxes have been recorded in municipal accounts as "assets," they have been refused as security for short-term loans to municipalities already burdened with a large floating indebtedness.

Caught in a vicious circle, with indebtedness constantly leading receipts, local governments have resorted to costly financing methods, such as tax anticipation warrants, issuance of bonds at high interest charges and consumption of reserves. Meanwhile the effectiveness of any enforcement of liens by tax sales has been largely nullified by the traditional leniency of the courts toward such sales. Where the accumulated taxes amounted to more than could be realized from a tax sale, the government could resort to the dubious remedy of purchasing the property, thus removing it from its own tax rolls. In the case of voluntary delinquency it has frequently been under the necessity of accepting reduced cash payments from taxpayers who have meanwhile enjoyed

${ }^{1}$ This analysis is based upon a paper read before the Special Committee on Municipal Law at the American Bar Association convention, July 17, 1935.

2 The tax delinquencies of certain representative cities had mounted to nearly $19 \%$ in 1932 , whereas $15 \%$ is regarded as the maximum margin of safety. Othe: evidence of mounting delinquency is cited in the compichersive study Administration of Mfunicipal Credit (1934) 43 YALE L. J. 924, 925. Representative data for 1932-1933 indicated an average delinquency of over 20\%. Report on Tax Delinquency (1934) 27 Proc. Nat. TAX Ass'N 319, 330.

3 The available statistics show that sixty to seventy per cent of local revenues are still derived from this tax. See Notes (1934) 43 Y ALE L. J. 924, 92S: (1934) 27 Proc, Nat. Tax Ass'N 356.

+ Sce Enslow, H. R., Tax Collection and Adjustment Plans (1035) 13 Tax M^G. 531 
the use of their money for other purposes without penalties. The fruitlessness of late enforcement in the first instance, and the substitution of concessions for penalties in the second, ${ }^{5}$ have accustomed the taxpayer to lax enforcement, with deplorable effects on subsequent collections. No private business could survive if it showed the same leniency toward its debtors that municipal governments have extended to their taxpayers, including those who were well able to pay.

The Model Real Property Tax Collection Law, ${ }^{6}$ sponsored by the National Municipal League, is concerned with ensuring effective collection. The authors seek to prevent the translation of the temporary financial straits of the taxpayer into the permanent financial straits of the municipality by a flexible collection system of four instalments within a unified tax calendar, without discounts and with graduated penalties for delinquency. The law would thus seek to prevent involuntary delinquency by allowing a rigid tax obligation to be liquidated through deferred payments. ${ }^{7}$ Having facilitated such liquidation, it then provides for expeditious enforcement of a lien in the event of delinquency, the finality here being justified by the leniency in the first stage of collection. The tax collector may, however, adjust the method of enforcement to the varying situations that may arise. If the tax has been delinquent for more than six months, he may act as receiver $e x$ officio of the rents and income of the property, provided it be neither residence nor farm property, and apply them to the payment of delinquent taxes. If the tax is still delinquent on the October first following the end of the fiscal year in which the lien attached, the collector is under mandatory duty to enforce the lien through sale of the property, though any failure to do so does not impair the lien. These provisions, together with the imposition of personal liability and the appointment of a bonded collector, should go far to make collection effective.

What of the relative merits of the preventive and punitive treatment of delinquency provided for by the Law? Undoubtedly the installment distribution of the tax burden ensures payment of some taxes which

${ }^{5}$ There has been an alarming increase of such concessions. The time for paying certain 1934 or 1935 taxes is, or may be extended under the laws of ten states. Twenty states have waived or reduced penalties or interest on delinquent taxes, while five have reduced the interest on future delinquencies. Seven states have postponed tax sales, and twelve have extended the time for redecming from past sales, usually with a reduction of interest or penalties. Finally fourteen states have allowed payment of delinquent taxes over a period of years, usually with reduced interest or penalties. The refercnces to the state laws are in the paper State Tax LegislaTION, 1935 read by Raymond E. Manning, of the Library of Congress; pp. 22-23, before the 1935 Conference of The National Tax Association, mimeographed copies of which are available.

The full text of the law appears in (May, 1935) Supplement to the National Municipal Review, v. XXIV, no. 5, pp. 290-305.

7 The governments could finance such payments through short-term loans at much less expense than if they were compelled to borrow without the security of certain receipts. The problem is ably discussed by Simpson, Tax Delinquency: Economic Aspects (1933) 28 ILL. L. REv. 147, 157. 
could not be met in a lump sum, and would satisfactorily prevent cumulative delinquency under ordinary circumstances. Over a long depression, however, the credit facilities of the taxpayer contract simultaneously with his income, so that he might be unable to finance his tax obligations even on a deferred payment basis. The Model Law might well supplement its provision for installment payments, therefore, with some plan of extending credit facilities to the taxpayer, enabling him to maintain his property values at a marketable level, rather than allowing such values to be borne down by cumulative tax delinquency.

It might be well to investigate in this connection the accredited lending corporations operating under the Orlove plan adopted last year in New York. ${ }^{8}$ Municipal governments may accept tax payments from these corporations in return for conditional tax receipts, thereby ensuring themselves of prompt payment. The taxpayer may avoid delinquency and its ensuing penalties by reimbursing the corporation which pays this tax, through twelve notes of equal amount, maturing monthlv, at $4 \%$ interest plus a $2 \%$ service charge, with a $6 \%$ rate becoming effective upon default of the loan. This makes credit for prompt tax payments available to any taxpayer whose property is worth at least more than the amount of taxes and penalties. In the event of a $\operatorname{tax}$ sale for delinquent taxes, the lending corporations should serve to stabilize at a low figure the interest rate accepted by the purchaser of the lien. The lending corporation is itself protected against default, for the municipality must refund to it from the proceeds of the sale the amount due it on its loan contract with the borrower. With such a plan the taxpayer, according to his financial circumstances, could either pay his taxes directly in four installments without interest, or could finance that payment through a loan to be repaid in twelve installments at a low rate of interest. It would seem advisable thus to limit the number of installments without interest to four, as the Model Law has done, and to charge the taxpayer with the expense of any additional leniency in the distribution of his tax obligation. ${ }^{9}$

The receivership system incorporated in the Law, while of comparatively recent origin, ${ }^{10}$ bids fair to be one of the most effective, as well as one of the most equitable means of enforcing tax liens. In 1921 a Tennessee statute authorized receiverships in pending tax suits for the

8 Described in Paul Studenski, A Tax Finance Plan for the Collection of Delinquent and Current Real Estate Taxes (1935) 13 TAX MaG. 131.

9 The expense of tax billing and accounting should discourage unnecessary installments. Ten such installments, however, have this year been permitted under Ohio S. B. 221. Certain municipalities have also attempted a similar method of offcial "savings accounts" for the payment of taxes, the results of which are unfavorably commented upon in (1934) 27 Proc. NAT. TAX Ass's 319, 361.

10 Such remedies are now in effect in Illinois, New Jersey and Ohio. See IrL. Rev. Stats. (Smith-Hurd, 1929) c. $120, \$ 240 ;$ N. J. Stat. Serv. (1934) $\$ \$ 208-444 a$; Gen. Code Orio (Baldwin's Supp., 1934) $\$ \$ 5703,5703-1,5703-2,115$ Ohio Laws, 1934, pt. 2, House Bill 28. 
first time. ${ }^{11}$ The Kerner-Skarda Act in Illinois ${ }^{12}$ and the Stout Act in New Jersey ${ }^{13}$ have expedited this process by authorizing receivers to collect income on property delinquent for more than six months, even where no suit is pending. Such legislation undoubtedly partially accounts for the improvement of several hundred per cent in the tax collections of Illinois. The tremendous increase represented in large part voluntary payments stimulated by the mere threat of receivership. Such a remedy is particularly effective against apartment houses, office buildings and similar income-producing property, and its constitutionality would seem beyond doubt. Certainly if the state can sell the property outright, it could appropriate the income therefrom: the right to seize a part would seem implied in the right to seize the whole. Nor should it be necessary to make the tax specifically a lien on the rents and income. Receiverships for the payment of private obligations are common, although no lien exists on the rents and income. ${ }^{14}$ Personal property, itself free from any lien, can be distrained for the collection of delinquent taxes on real property. ${ }^{15}$ Certainly receivership seems less drastic than either of these remedies.

Ordinarily the court which first appoints a receiver has exclusive jurisdiction over the property, and other courts cannot appoint an additional receiver. ${ }^{16}$ Whether appointed by state or federal courts, he must generally conform to state tax statutes ${ }^{17}$ and must pay state taxes as a preferred claim regardless of whether they became due before ${ }^{18}$ or during ${ }^{19}$ the receivership. The Model Law specifically restates this duty in all cases where the collector is made receiver of the rents and income of the property. Such a provision, if made at all, should not necessitate the appointment of the collector as a receiver for payments due in his capacity as collector.

The receiver is given the power of an assignee of the rents and

11 TENN. CODE (1932) \$1602.

12 ILL. Rev. Stats. (Smith-Hurd, 1929) c. 120, \$ 240. Discussed by Earl H. De Long, Tax Delinquency-The Illinois Tax Receivership Act (1933) 28 ILL. L. Rev. 379.

13 N. J. Stat. Serv. (1934) $\$ \$ 208-444 a$.

14 See Cal. Code Crv. Proc. $\$ \$ 564$ el seq.

15 Scottish Union Ins. Co. v. Bowland (1905) 196 U. S. 611; Wolfe v. De Wolfe (1931) 53 F. (2d) 999. See also, Nickey v. Mississippi (1934) 292 U.S. 393, holding that a state may collect taxes assessed against one parcel of property by resort to other parcels of property within the state owned by the same person, though he be a non-resident.

16 Shields v. Coleman (1895) 157 U.S. 168; Palmer v. Texas (1908) 212 U.S. 118; Tenth Nat. Bank of Philadelphia v. Smith Construction Co. (1910) $227 \mathrm{~Pa}$. 354,76 Atl. 67.

17 Gillis v. California (1934) 293 U. S. 62.

18 Marshall v. New York (1920) 254 U. S. 380; Witt v. Jones (1925) 106 Okla. 227, 233 Pac. 722.

10 Michigan v. Michigan Trust Co. (1932) 286 U. S. 334 ; Coy v. Title Guarantee and Trust Co. (1915) 220 Fed. 90; Central Trust Co. v. N. Y. and N. R. Co. (1888) 110 N. Y. 250,18 N. E. 92. 
income of the property, and is authorized to pay expenses necessary to keep the property tenantable. Since he need post no other than his official bond as collector, it would seem advisable to require, as a protection to the property owner, court approval of such expenses. The narrow scope of his powers probably precludes the receiver from actually managing the property. It might, however, be well to authorize him to make and renew leases and to undertake other contracts in the management of the property, subject of course to court approval. Some provision should also be made allowing the property owner to petition for termination of the receivership in the event of mismanagement.

The Model Law should also make clearer the relationship between the receivership provisions and the tax sale provisions. It places the collector under mandatory duty to epforce liens by sale on the October first following the end of the fiscal year on which they have attached. At the same time it authorizes the appointment of the collector as receiver of any property on which the taxes or any instalment thereof have been delinquent for more than six months. Some confusion might arise from the overlapping dates of these remedies. Must the property be sold, even though it is already in the hands of the receiver? If so, what becomes of the receivership? Would it be automatically terminated by the tax sale or would it continue in order to repay the purchaser at the tax sale, and thus redeem the property? If the May 1st installment were delinquent, the property could be sold before the receivership provisions could apply. Should receivership be allowed for property which has thus been sold? These problems, together witb that of the proper time for enforcing the personal liability, could be simply resolved by providing that the remedies be cumulative, and that no action taken to secure collection of the tax shall be construed as an election to pursue one remedy to the exclusion of others.

The mandatory tax sales provided by the Model Law must be continued from day to day without adjournment. The sale is at public auction for the amount of the lien to any person who would purchase the property subject to redemption at the lowest interest rate not in excess of $12 \%$ per annum. The purchaser is entitled to semi-annual payment of the interest stipulated at the sale and to prompt payment when due of all subsequent taxes and other municipal charges which may become a lien upon the property. Failure of the owner to comply with these conditions gives the purchaser an immediate right to foreclose the right of redemption. The purchaser obtains a certificate of sale which, if not recorded within three months of the date of sale, is void against a bona fide purchaser, lessee, or mortgagee whose deed, lease or mortgage is recorded before the recording of the certificate. Property for which there is no other purchaser is sold subject to redemption at $10 \%$ per annum to the taxing district which has the same rights as other purchasers. The Law authorizes a private sale of the certificate for not less than the amount stated therein, together with the municipal 
liens subsequently charged against the property. Any person having an interest in the property may redeem within one year from the date of sale, or thereafter until the right to redeem is foreclosed, by paying the amount stated in the certificate, interest, and expenses of the purchaser incident to the sale. Alternative proceedings in personam or in rem are provided for the expeditious foreclosure of the right of redemption.

These provisions need clarification. Some ambiguity, for example, inheres in the provision that the certificate of sale shall be "presumptive evidence" of the truth of the statements therein, of the purchaser's title, and of the regularity and validity of the sale and related proceedings. The phrase "presumptive evidence" has in the past led to considerable confusion. ${ }^{20}$ It creates a doubt whether the introduction of the certificate raises a mere presumption which is permanently dispelled by counter evidence, or whether it makes out a prima facie case which must be considered together with the counter evidence. The certificate should be given more weight than a mere presumption. If the purchaser is to be adequately protected the certificate should be made prima facie evidence of the truth of the statements therein and the regularity and validity of the sale and related proceedings.

The Law further provides that after two years from the recording of the certificate of sale no evidence shall be admitted in any court to rebut the presumptive evidence of the certificate except in cases involving fraud. The constitutionality of such provisions is questionable, ${ }^{21}$ although they are sometimes sustained as statutes of limitation. ${ }^{22}$ It is arguable that the right to prove that the property was exempt from taxation, that notice of sale was not given, or other facts as essential as those relating to fraud cannot be taken away without a denial of due process of law.

It would seem advisable also that the period within which presumptions may be rebutted should run from the time the certificate is issued rather than from the date of its recordation. Why should the purchaser be under the necessity of recording the certificate of sale? The interest of the certificate holder during the period of redemption is not made clear, but whatever his interest the collector's records should show the existence of the lien and constitute sufficient notice to all persons dealing with the delinquent owner. Bidding for the property should be encouraged by minimizing the requirements of purchasers to those essential to the rights of the delinquent. It would seem no more necessary for the purchaser to record the certificate than for the municipality to record the levy of the tax. Judgment rendered in the foreclosure

20 See Edmund Morgan, Presumptions and the Burden of Proof (1933) 47 Harv. L. Rev. 59; Notes (1932) 20 Calir. L. Rev. 189; (1930) 4 Cin. L. Rev. 89; 3 WIGMORE, EVIDENCE (2d ed. 1923) \& 1456; 5 ibid. $\$ \$ 2490$ to 2494.

${ }^{21}$ See 2 Wigmore, Evidence (2d ed. 1923) \& 1353; Marx v. Hanthorn (1893)

148 U. S. 172.

22 (1906) 8 L. R. A. (N.S.) $157,160$. 
proceedings, however, giving title in fee simple, should be recorded since it removes the lien and creates a new title which might not appear in the records of the tax collector.

There is no sharp distinction between the in personam and in rem proceedings provided for the foreclosure of the right of redemption. Some differentiation might exist if personal service is required in the one whereas only service by publication is required in the other. Since the certificate holder, however, may elect the procedure he desires to follow, a simple provision that either personal service or service by publication at the option of the holder would obviate any necessity for two distinct proceedings. Perhaps the Law intended to make a personal judgment available in the in personam, but not in the in rem proceeding, since it explicitly provides that no personal judgment shall be entered in the in rem proceeding. A personal judgment, however, might be precluded by the absence of specific authorization as well as by the provision that the final judgment in such proceeding shall give the certificate holder title in fee simple. This provision makes clear that neither a sale of the property nor a deficiency judgment is contemplated in such proceeding.

The personal liability imposed by the Model Law is limited to residents on the ground that its extension to non-residents might be unconstitutional in view of Dewey v. Des Moines ${ }^{23}$ and City of New York v. McLean. ${ }^{24}$ The first case invalidated a personal judgment against a non-resident for an improvement assessment upon real property. The non-resident, however, never appeared in any of the proceedings leading up to the levying of the assessment and was not personally served with process in the state. The second case held that personal liability for a tax levied by the City of New York could not be imposed, under the statutes involved in that case, upon a non-resident, even though he were personally served in the state. Neither case involved the constitutionality of a statute explicitly imposing personal liability upon non-residents personally served with process in the state. Subsequent cases in the state courts on this precise issue have uniformly beld such statutes valid. ${ }^{25}$ The United States Supreme Court in Bristol v. Washington Count ${ }^{26}$ did much to explain the scope of its decision in the Des Moines case in stating that "What was ruled there was that a citizen of one State cannot be cast in a personal judgment in another State on an assessment levied there on real estate for a local improvement without service on him or voluntary appearance, or some action on his part amounting to consent to the jurisdiction." These cases

23 (1899) 173 U. S. 193.

24 (1902) 170 N. Y. 374,63 N. E. 380.

25 Greenbaum v. Commonwealth (1912) 147 Ky. 450, 144 S. W. 45 ; Collector of Taxes v. Rising Sun Street Lighting Corp. (1918) 229 Mass, 404, 118 N. E. 871 ; State v. Baker (1930) 35 N. M. 55, 289 Pac. 801 , cert. den. (1930) 282 U. S. 807. See Note (1931) 44 Harv. L. Rev. 1265.

28 (1900) 177 U. S. $133,146$. 
would justify the extension of the provision to non-residents personally served within the state. Nothing would be lost by the inclusion of such a provision and much might be gained if it proved valid. Certainly a state should make every effort to avoid discrimination against its own citizens by subjecting all taxpayers to the same liabilities. It is probably true that any property in the state upon which execution could be levied in satisfaction of a personal judgment might also be reached by distraint proceedings ${ }^{27}$ or by attachment, ${ }^{28}$ thus avoiding the constitutional questions just discussed. A personal judgment, however, would operate less harshly, and might also form, although the question is still an open one, ${ }^{29}$ the basis of an action in other states in which the taxpayer has property that could be reached to satisfy the judgment.

Collections under the Model Law might be greatly facilitated by the consolidation of assessment and collection procedure within coordinated taxing districts. While the introduction to the Law recommends serious consideration of such unification of tax functions, such a plan is quite properly excluded from the Law itself in view of the political and constitutional differences of the various states. The Law limits itself to a provision that the assessed values of the largest taxing unit shall be uniform for all districts entirely within its limits. Similarly the appointment, tenure, powers and duties of the assessor, the method of appointing the collector, the description of assessed property, and the extent of state supervision over local tax authorities are properly left by the Law to each state to work out against its own background.

The incorporation of certain other details through supplementary legislation is also left to each state. The Law, for example, does not provide for notice to the taxpayer of the values placed upon his property, nor for hearings before the tax board for the equalization of his assessment. The tax calendar is suggestive only; this perhaps explains the omission of a fixed tax day. One might by implication assume it to be January 10th, the day fixed for completing the assessment list and filing it with the board of taxation. It could, however, plausibly be October 1st, when the assessing begins; any date between October 1st and January 10th, as determined by the assessor; or any day between January 10 th and July 1st, depending upon when the tax rate is finally fixed. The establishment of a specific tax day would obviate any confusion resulting from changes in ownership, changes in the exempt status of property, fluctuations in values, destruction of property, erection of new buildings, and the attachment of personal liability for taxes.

27 See Scottish Union etc. Ins. Co. v. Bowland (1905) 196 U. S. 611.

28 See Nickey v. Mississippi, supra note 15.

20 See Wisconsin v. Pelican Ins. Co. (1888) 127 U. S. 265; Moore v. Mitchell (1929) 30 F. (2d) 600 Cf. People of State of New York v. Coe Mfg. Co. (1934) 112 N. J. L. 536, 172 Atl. 198, cert. den. (1934) 55 Sup. Ct. 89 : (1935) 83 U. or PA. L. REv. 387; Hazlewood, Full Faith and Credit Clause as Applied to Enforcement of Tax Judgments (1934) 19 MARQUETTE L. REv. 10. 
The introduction to the Model Law raises a question regarding the desirability of either transforming any real property subject to a municipal lien into municipal property not in the custody of the law, or making the lien indestructible, and therefore enforceable, after the close of bankruptcy proceedings. It is doubtful whether a state statute could now withdraw such property from the jurisdiction of the bankruptcy court without conflicting with the power of the federal government over bankruptcies. ${ }^{30}$ Numerous cases ${ }^{31}$ hold that the bankruptcy court acquires the exclusive right to administer all property in which the bankrupt has a beneficial interest. Title and right to possession of all property owned and possessed by the bankrupt vests in the trustee as of the date of filing the petition for adjudication in bankruptcy, regardless of whether the property is situated within or without the district in which the court sits. ${ }^{32}$ Only an amendment to the Bankruptcy Act would clearly legalize the transformation of bankrupt property subject to a tax lien into municipal property. Such a change, however, would frustrate the marshalling of all the assets of the bankrupt for a final adjustment of his affairs. Ordinarily the value of property greatly exceeds the amount of the taxes claimed due, and it would accordingly be unjust to withhold that excess from other creditors. The municipality is already adequately protected by a lien upon the proceeds of the bankruptcy sale and its prior claim for the payment of the taxes due.

The creation of an indestructible lien would probably be unconstitutional under the decision of the United States Supreme Court in Van Huffel v. Harkelrode, ${ }^{33}$ holding that under the general equity powers of the bankruptcy court and the powers implied from Section 2 of the Bankruptcy Act, an order could be entered directing that real property be sold free and clear of encumbrances, including state tax liens.

The Model Law would not operate retroactively to liquidate the abnormal amount of existing delinquency. It could, however, be supplemented by a related program, adapted to the local situation, for liquidation of tax arrears, involving perhaps receiverships for incomeproducing property, and the active execution of tax sales. The tax collector could in many cases distinguish between voluntary and involuntary delinquency, and adjust his method of enforcing the lien accordingly. Such a program, reënforced by organized tax payment campaigns, would hasten the realization of frozen assets, and encourage municipalities to undertake with greater security the provisions of the Model Law for installment payments.

30 International Shoe Co. v. Pinkus (1929) 278 U. S. 261; New York v. Irving Trust Co. (1933) 288 U. S. 329

31 White v. Schloerb (1900) 178 U. S. 542 ; Murphy v. John Hofman Co. (1909) 211 U. S. 562 ; Herbert v. Crawford (1912) 228 U. S. 204; Lazarus v. Prentice (1914) 234 U. S. 263 ; Straton v. New (1931) 283 U. S. 318.

32 Isaacs v. Hobbs Tie \& Timber Co. (1931) 282 U. S. 734

83 (1931) 284 U. S. 225 , commented upon in (1932) 20 CALIF. L. REv. 645. 
Property with a record of chronic delinquency has sometimes been restored to local tax rolls, as in Nebraska, ${ }^{84}$ through sale, unencumbered by liens, to the highest bidder. It is a dangerous if heroic remedy, however, to sell property for less than the amount of accrued taxes. It would always be possible for the government involuntarily, or the taxpayer deliberately to underestimate the value of the property. Once the precedent were established of selling property for less than the amount of accrued taxes, the effectiveness of any tax sales as a method of enforcing liens would soon be destroyed. In any event little could be lost by removing such property from the tax rolls and either devoting it where possible to some permanent municipal use or at least withholding it from private ownership so long as it were unable to yield taxes under such ownership. ${ }^{25}$

SCHOOL OF JURLSPRUDENCE,

Roger J. Traynor. UnIVERSITY OF CAL.IPORNI.

Reorganizations; Amendments to the Callfornia Corporate Securities ACT.-The Division of Corporations has adopted certain rules governing corporate reorganizations, certificates of deposit and definitive securities which are set forth in Chapter 36 of the Rules of Practice of the Division of Corporations. These rules were commented on in the March number of the California Law Review in a note ${ }^{1}$ which dealt with the interaction of the State Corporate Securities Act, the Federal Securities Act and the Federal Corporate Reorganization Act. ${ }^{2}$ These rules of practice were developed by the Commissioner of Corporations in order to meet the exemption set forth in Section 3 (a) 10 of the 1934 Federal Securities Act, which exempted from Federal regulation securities to be exchanged for outstanding securities:

"where the terms and conditions of such issuance and exchange are approved, aiter a hearing upon the fairness of such terms and condition at which all persons to whom it is proposed to issue securities in such exchange shall have the right to appear, by ... governmental authority expressly authorized by law to grant such approval."

These rules set forth in Chapter 36 of the Rules of Practice concerning reorganization hearings were promulgated by the Commissioner of Corporations under the express grant of rule-making power and under the express grant of authority to issue permits authorizing the issue of securities. ${ }^{3}$ The minimum findings required to be made to satisfy the

31 Neb. CoMrp. Stat. (1029) \$ 77-2039.

35 See Lent D. Upson, Tax Delinquency: Administration and Legislation (1934) 27 Proc. Nat. Tax Ass's 356, 365.

\footnotetext{
${ }^{1}$ Note (1935) 23 Caltf. L. Rev. 348.

${ }^{2}$ Nat. Bankruptcy Act 877 B, 48 Stat. (1934) 91; Note (1935) 23 Calm. L. REv. 348-351.

${ }^{3}$ Cal. Corporate Securtties Act \& 5, Cal. Stats. 1931, p. 943.
} 
exemption in Section 3 (a) 10 of the Federal Securities Act exceed the minimum findings required under the California Corporate Securities Act. Under the California Act it is only necessary that the ('ommissioner find that the issue is not unfair, a negative finding. rather than make the minimum finding required by the Federal Act "that it is fair to make the exchange of securities."

In order to remove any doubt as to the Commissioner's authority to make the positive finding that the issue of securities in exchange for outstanding securities is fair, the 1935 legislature adopted the following amendment to the second paragraph of Section 4 of the Corporate Securities Act:

"Pursuant to this act the Commissioner has been and is authorized. in the instance of an application for a permit to issuc securities in exchange for one or more bona fide outstanding securities, claim or property interests, or partly in such exchange and partly for cash, to approve the $t \mathrm{crms}$ and conditions of such issuance and exchange and the fairncss of such terms and conditions.... at which all persons to whom it is propo-ed to issue securities in such exchange shall have the right to appcar." 4

This measure was adopted as emergency legislation and was approved by the Governor on May 17,1935, becoming efiective immediately.

Chapter 36 of the Rules of Practice of the Division of Corporations has been amended to conform with this emergency legislation. (Copies of these rules are available for public distribution at nominal cost at any office of the Division of Corporations.)

\section{Certificates of Deposit Made Subject to Cokpokate SECURITIES ACT}

In many reorganizations a committee representing holders of bonds or securities upon which the issuer was in default as to interest or principal or other requirements of the trust indenture. in order to act effectively in behalf of large numbers of holders of outstanding securities, has arranged for the solicitation of the deposit of such securities with the Committee. Such deposit is made under an agreement giving the Committee control over the securities for the purpose of carrying out the reorganization plan. The holder of the outstanding security in these cases has been given a certificate of deposit in exchange for his security. The issue of such ccrtificates of deposit has been subject to the Federal Securities Act when issued in interstate commerce. Practicaliy every important security issue, although originally issued entirely within the state of California, was found by the Reorganization Committee to be held in part outside the state at the time the certificates of deposit were to be issued by the Committee. This necessitated compliance with the registration requirements of the Federal Securities. Ict with the consequent cost. labor and loss of time. There was also the disadvantage of the unfamiliarity of the district Federal authorities with the facts already fully known to the California Division of Corporations.

\footnotetext{
4 Cal. Stats. 1935 , c. 166.
} 
Unfortunately the 1933 Corporate Securities Act of California specifically exempted from its jurisdiction any issue of certificates of deposit to holders of outstanding securities, so that there was no possibility of a hearing under Chapter 36 of the Rules of Practice to avoid registration under the Federal Securities Act. In these cases the Reorganization Committee either had to act without the benefit of authority from certificate holders, or if it wished to issue certificates of deposit, it had to comply with the Federal Securities Act.

In order to cure the lack of authority of the Commissioner of Corporations over the issue of certificates of deposit and thus gain the benefit of exemption from the Federal Securities Act the 1935 legislature amended the Corporate Securities Act, Section 2 (a) 7 defining the term "security" expressly to include "certificates of deposit" and to repeal the former exemption of certificates of deposit in that definition.

The 1935 legislature also amended the fee section of the Corporate Securities Act, Section 26 (10) to provide that the fee for filing an application for a permit to issue certificates of deposit shall be $\$ 25$ plus a sum as estimated by the Commissioner to cover the actual expenses of noticing and holding any hearing in connection therewith.

Of course after authority to issue and the issuance of the certificates of deposit by the Committee, there may be an exchange of modified or new securities for the outstanding securities, obligations, or property interests in carrying out the complete reorganization plan. In such case an additional permit must be applied for and obtained to authorize the issue of such modified or new securities.

\section{FEes}

The Corporate Securities Act was further amended by the 1935 legislature in relation to the fee schedule for applications for permits in general for the purpose of bringing the fees more nearly in line with the experience of the Division of Corporations as to the approximate cost involved in handling applications for permits, it having been found that the old schedule of fees did not approximate the cost of handling applications. The new fees start with fifteen dollars instead of ten as a minimum and set the amount within said minimum up to five thousand dollars value of paid securities for which application is filed. The schedule then provides for an additional percentage between certain minimum and maximum amounts, the percentage decreasing as each bracket increases in amount. ${ }^{5}$

Donald A. Pearce.

Deputy Commissioner of Corporations, Statz of Caltrornu.

${ }^{5}$ See section 26 of Cal. Corporatr Securitiss Act, as amended by Assembly Bill 1663, effective Sept. 15, 1935. 